\title{
WORKING-CLASS WRITING AND \\ PUBLISHING IN THE LATE TWENTIETH CENTURY
}

\section{Literature, culture and community}

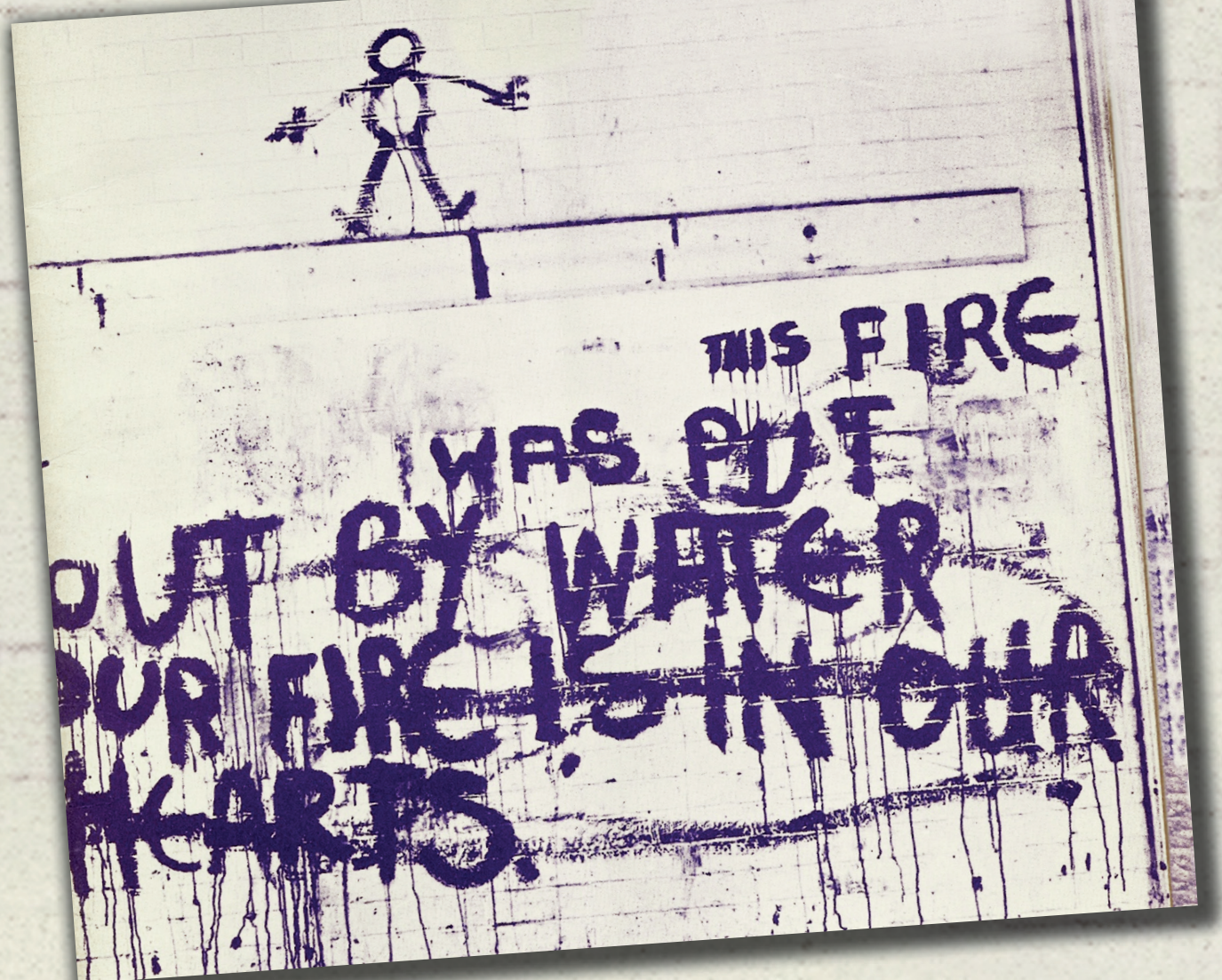

Tom Woodin 


\section{Working-class writing and publishing in the late twentieth century}

\section{MANCHESTER

$$
1824
$$

Manchester University Press 
Tom Woodin - 9781526108609 Downloaded from manchesterhive.com at $04 / 26 / 2023$ ०8: 09 :23AM via free access 


\section{Working-class writing and publishing in the late twentieth century}

Literature, culture and community

Tom Woodin 
Copyright (C) Tom Woodin 2018

The right of Tom Woodin to be identified as the author of this work has been asserted by him in accordance with the Copyright, Designs and Patents Act 1988.

Published by Manchester University Press

Altrincham Street, Manchester M1 7JA

www.manchesteruniversitypress.co.uk

British Library Cataloguing-in-Publication Data

A catalogue record for this book is available from the British Library

ISBN 9780719091117 hardback

First published 2018

The publisher has no responsibility for the persistence or accuracy of URLs for any external or third-party internet websites referred to in this book, and does not guarantee that any content on such websites is, or will remain, accurate or appropriate.

Typeset in 10/12.75 Joanna by

Servis Filmsetting Ltd, Stockport, Cheshire 